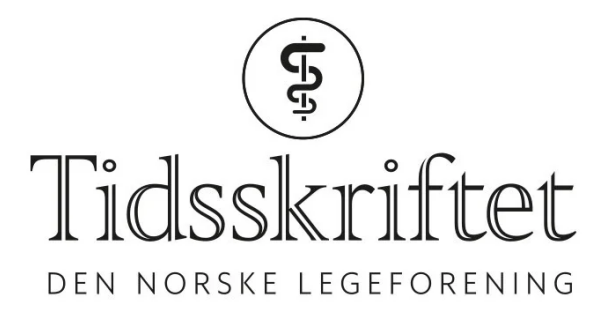

\title{
Overivrige små klinikere
}

TIDLIGERE I TIDSSKRIFTET

SYNNE LOFSTAD

synne.lofstad@hotmail.com

Redaksjonssjef i Æsculap

Vi har alle vært der. I et akuttmottak for å ta opp våre obligatoriske journaler. Noen har kjent på følelsen av å være i veien om det er travelt. Andre på kjedsomheten når man sitter og venter på en "passende pasient for en student». Konkurransen med kullinger om å få den første pasienten, og med studenter på hospitering fra andre universiteter. Kommunikasjonen mellom studentene, legene og sykepleierne er kanskje ikke alltid på topp (Æsculap 1997; 77(3): 9).

\section{Kaos på KAM}

Et stadig tilbakevendende problem er at akuttmottaket ved Ullevål sykehus overfylles av studenter i 9. termin. KAM utgjør pasientenes første møte med sykehuset, og det er viktig at de vises den respekten de fortjener. Det er derfor et problem når for mange uerfarne studenter hiver seg over de nyinnkommede, og på den måten hindrer sykepleiernes rutinearbeid. 


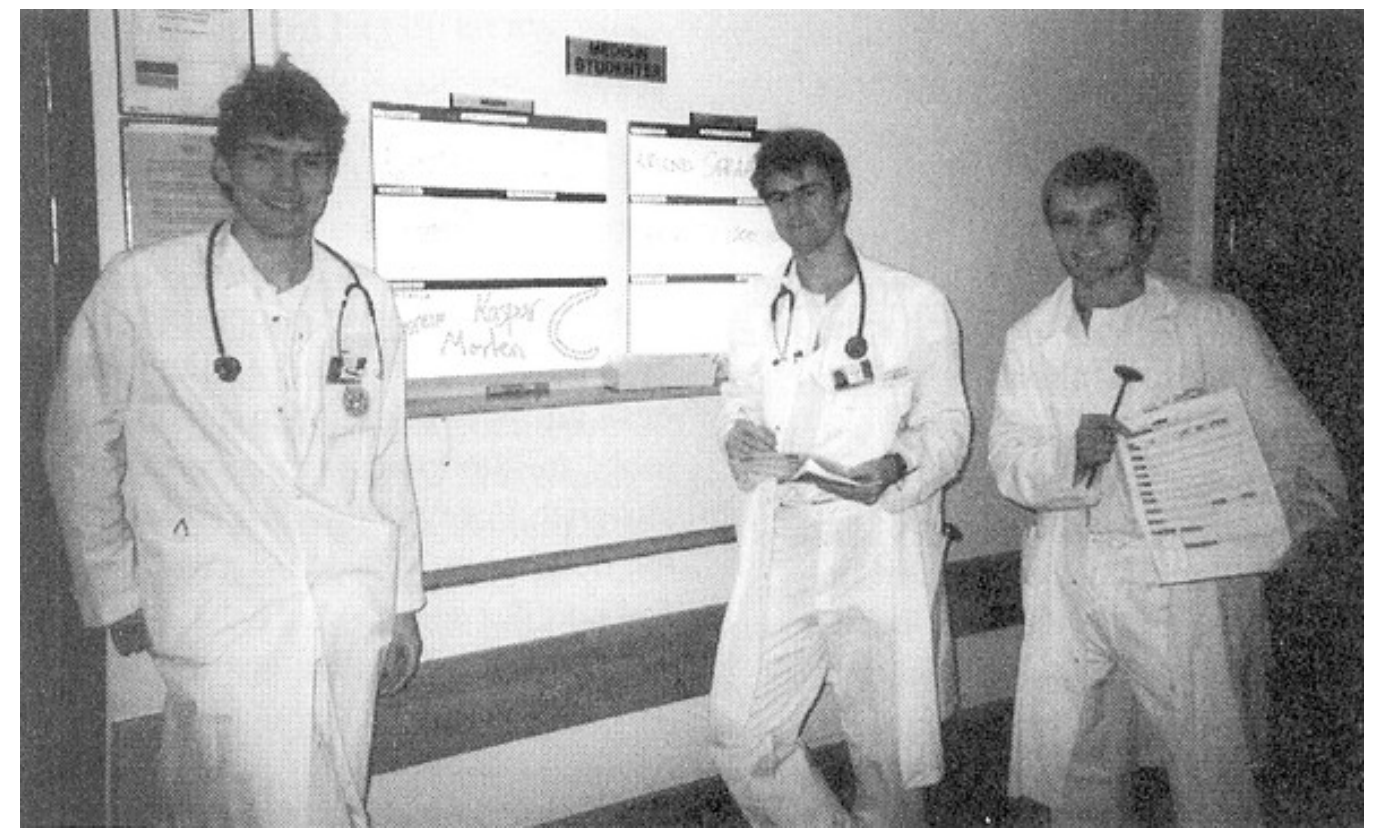

Disse tre studentene fra C-partiet ble tatt på fersk gjerning idet de alle befant seg inne på mottaket. Dette er strengt forbudt, normalt skal det bare være én fra hvert parti til stede om gangen. Foto: Sykepleier, KAM

Spesielt på grunn av én kveld har tillitsmannen på kullet mottatt klager. Da var det hele 7 studenter fra 9. termin i mottaket, hvorav 3 opptok plass nær inngangsdøren og hindret adkomsten til sykepleiernes kaffekrok. Videre tok 3 studenter opp journal, og minst én av disse snakket svært høyt. Dessuten var en av studentene i veien der han dikterte på studentrommet.

Noe av skylden må den legen ta på seg som satte hele 4 studenter i gang med journalopptak. Vedkommende burde ha visst at det maksimale antall studenter tillatt er tre. Dette tallet er endelig, og gjelder enten studentene er der for å ta opp journal, følge en lege gjennom området eller for å undersøke om det virkelig er tre studenter tilstede allerede. Enkelte studenter har også oppfattet det dithen at det er mulig å snakke med sin veileder, som oppholder seg på KAM, selv om det allerede er tre studenter på området. Dette er ikke tilfelle.

Når det er for mange studenter tilstede, skaper dette store problemer for akuttmottaket. Det er rapportert at inntil 4 av sykepleierne har vært så opptatt med å telle antall studenter at KAM ikke har hatt ressurser til å ta seg av de nye pasientene på en skikkelig måte. De sykepleierne som ikke teller, blir stadig forstyrret av at studenter i forsøk på å snike i journalkøen, og trenger seg inn på rommene. Dette fører til at EKG-elektrodene sjelden blir plassert riktig i mottaket (jmfr. prof. Gjesdal).

Vi har stor respekt for at enkelte studenter er ivrige og ønsker å bruke mye tid på faget sitt. I preklinikken var dette uproblematisk. Men når de studentene som før brukte all sin tid på å lese Berne \& Levy (referanseboken til fysiologiforeleserne) har begynt i klinikken, må de lære seg å ta hensyn til sine medstudenter. I klinikken er det viktig at alle medisinerne får like mye erfaring, og det er urettferdig når enkeltes overivrighet går ut over de mer forsiktige studentene.

Hvis ikke situasjonen med hensyn til journalopptak i mottaket bedrer seg, er det fare for at KAM må legges ned. Dette er noe ingen er tjent med, hverken pasienter, sykepleiere eller studenter.

Oppgitt student

Publisert: 17. september 2020. Tidsskr Nor Legeforen. DOI: 10.4045/tidsskr.20.0645

(C) Tidsskrift for Den norske legeforening 2023. Lastet ned fra tidsskriftet.no 26. april 2023. 